\title{
Quality assessment of groundwater at Laksar Block, Haridwar in Uttarakhand, India using Water Quality Index: A case study
}

\section{Rakesh Bhutiani}

Limnology and Ecological Modelling Lab. Department of Zoology and Environmental Science, Gurukula Kangri (Deemed to be University), Haridwar-249404 (Uttarakhand), India

\section{Faheem Ahamad}

Department of Environmental Science, Keral Verma Subharti College of Sciences (KVSCOS), Swami Vivekanand Subharti University Meerut-250005 (Uttar Pradesh), India

\section{Khushi Ram*}

Limnology and Ecological Modelling Lab. Department of Zoology and Environmental Science, Gurukula Kangri (Deemed to be University), Haridwar-249404 (Uttarakhand), India

*Corresponding author. Email: khushi2013ram@gmail.com

\section{Article Info}

https://doi.org/10.31018/ jans.v13i1.2435

Received: November 19, 2020

Revised: February 26, 2021

Accepted: March 3, 2021

\section{How to Cite}

Bhutiani, R. et al. (2021). Quality assessment of groundwater at Laksar Block, Haridwar in Uttarakhand, India using Water Quality Index: A case study. Journal of Applied and Natural Science, 13(1): 197 - 203. https://doi.org/10.31018/jans.v13i1.2435

\begin{abstract}
Urbanization and industrialization enhance the degradation of the groundwater quality due to the discharge of domestic and industrial effluents in the aquatic bodies or on the surface of ground either in treated or untreated form. Therefore, the present study was carried out to assess the groundwater quality at the Laksar block of district Haridwar in Uttarakhand. Groundwater samples (SS-1-10) were collected from the hand pumps of the study area. The sampling site (SS-1) was taken as control. The distance of all sampling sites from control site ranged from $6.3 \mathrm{Km}$ to $18.3 \mathrm{Km}$. The samples were analyzed for various physicochemical parameters viz Temperature, Electrical Conductivity (EC), Total Dissolved Solids (TDS), Total Solids (TS), pH, Dissolved Oxygen (DO), Total Hardness (TH), Calcium Hardness $(\mathrm{CaH})$, Chloride $(\mathrm{Cl})$, Sulphate $\left(\mathrm{SO}_{4}^{-{ }^{-}}\right)$, Nitrate $\left(\mathrm{NO}_{3}^{-{ }^{-}}\right)$, Acidity, and Iron (Fe) for two years (2017 to 2019). The data obtained after analysis was simplified using Water quality index (WQI). The maximum concentration of TDS, TS, TH, CaH, and Fe was observed at SS- 6 that may be due to the direct industrial discharge of Sugar mill effluent on the ground. Based on WQI value, SS-6 (WQI value-150.27) was found most polluted site. Hardness was found above the standard limit $(250 \mathrm{mg} / \mathrm{l})$ at SS-6 to SS-10. The Fe was also found above the standard limit of WHO and BIS $(0.3 \mathrm{mg} / \mathrm{l})$ at SS- 6 to SS-10. The study may be useful for managing the groundwater quality of the study area.
\end{abstract}

Keywords: Groundwater, Laksar block, Physicochemical parameters, WQI

\section{INTRODUCTION}

Groundwater is the most important natural resource used for drinking purpose. It is also used for agriculture, domestic and industrial activities (Sadat et al., 2014). Out of the total quantity of water present on the earth, only $3 \%$ is freshwater. Less than $1 \%$ of the available water is accessible for drinking purpose (Verma et al., 2018). Out of the entire sector, the maximum amount of groundwater is utilized in agriculture (Bhutiani et al., 2018a). Due to the excess use of water, two problems grow simultaneously. First is the reduced groundwater table and the second one is water pollution in ponds, lakes, rivers and streams along with groundwater through leaching as the maximum amount of water supplied to the human society return as wastewater
(Bhutiani and Ahamad, 2018). Groundwater pollution occurs due to both natural and anthropogenic factors. The industrial waste and domestic waste either in solid and liquid form is directly discharged or dumped on the ground either treated, partially treated or in untreated form (Kumar et al., 2018; Ruhela et al., 2020). The leachate form the solid waste percolates through the ground. Some pollutants get absorbed by the soil while some pollutants reached inside the ground and get mixed with the groundwater. Similarly, pollutants from liquid waste reached the groundwater (Saleh et al., 2020).

About $16 \%$ of all the deaths in developing countries are related to water pollution, which accounts for about 1.7 million deaths per year or 1 in 6 deaths (Biswas and Tortajada, 2019). Water pollution affects not only 
the quality of water but also human health. Water pollution is a great threat to economic development and social prosperity (Milovanovic, 2007). The causing factors of many of the diseases are water pollutants (Jain et al., 2010). The groundwater constitutes an essential nutritional component for growth and survival of certain species of biota. The industry and seasonal activities are responsible for the poor quality of groundwater in different areas of the country (Jain et al., 2010; Bhutiani et al., 2018b; Bhutiani et al., 2019; Kaviarasan et al., 2016). Therefore continuous monitoring of groundwater is made mandatory to reduce groundwater pollution and control over polluting agents.

Water quality index (WQI) helps in understanding general quality status of a water source and therefore has been applied to both surface and groundwater for the quality estimation all over the world form the last few decades (Kaviarasan et al., 2016; Khan and Jhariya, 2017; Verma et al., 2018; Adimallaa and Qiana, 2019; Vaiphei et al., 2020). Several workers have studied industrial impact on groundwater quality in different regions of India (Bhutiani et al., 2016; Toure et al., 2017; Kwami et al., 2018; Bahmani and Palangi, 2018; Rao and Latha, 2019). The present study was undertaken in Laksar Block of Haridwar district Uttarakhand India to assess the hand pumps water quality (ground water) using water quality index.

\section{MATERIALS AND METHODS}

\section{Sample collection and analysis Study area}

The present study was carried out in different villages (Niranjanpur (SS-1, control site), Bhikkampurjeetpur (SS-2), SultanpurAdampur (SS-3), Bukkanpur (SS-4), Bahdarpur Khaddar (SS-5), Laksar (SS-6), Dabki Kalan (SS-7), AkaudhaAurangzebpur (SS-8), KharanjaKutubpur (SS-9), Raisi (SS-10) of Laksar block, located in Haridwar district in the state of Uttarakhand. The average elevation of Laksar is 227 meters (745Feet). It is situated between the towns of Khanpur and Sultanpur. The Laksar block in the southeastern part of the district is a part of Khadar. Khadar is a localized term used for the floodplains of rivers and areas inhabited by sediments recently deposited by rivers. It mainly consists of fine sand, silt and clay. Unconfined aquifer is reported in the literature in the study area which means that water seeps form the ground surface directly above the aquifer (CGWB, 2016). Therefore, there is a great risk of pollution of groundwater in the study area due to release of industrial wastes directly on the ground and in aquatic bodies which in due course of time seeps underground from the earth along with pollutants. Some small and large scale industries are located within the study area (R.B.N.S Sugar mill, Birla tyres, Shri Cement). Groundwater table in the study area is at 30 to
40 feet. All the selected sampling sites (S1 to S10) of the study area are given in Table 1 and Fig. 1 .

The samples were collected in the morning hour form all the study sites for two years (2017 to 2019) on monthly basis. The samples were collected after 10 minute of pumping from each site in a Jerry can of 2liter capacity using Grab sampling method and were transported to the laboratory immediately. The samples were analyzed for the physicochemical parameters such as temperature, TDS, EC, TS, $\mathrm{pH}, \mathrm{TH}, \mathrm{CaH}, \mathrm{Cl}$, $\mathrm{SO}_{4}^{--}, \mathrm{NO}_{3}{ }^{--}$, and $\mathrm{Fe}$ using standard methods (APHA, 2012; Khanna and Bhutiani, 2008).

\section{Water quality index (WQI)}

Water Quality Index (WQI) is a very useful and efficient method, which can provide a simple indicator of water quality and is based on several important parameters. In the present study, the WQI was calculated using the weighted arithmetic index method of Cude (2001) and Brown et al. (1970). In this model, the components with different water quality are multiplied by a weighting factor and then collected using a simple arithmetic mean. To assess water quality first, a Quality Rating Scale (Qn) was calculated for each parameter

$$
Q n=\frac{V s-V i o}{S n-V i} \times 100
$$

Where,

$\mathrm{Qn}=$ is the Quality rating of nth parameter

$\mathrm{Vs}=$ Observed value of the water quality parameter obtained from laboratory analysis

Vio $=$ Ideal value of that water quality parameter can be obtained from the standard Tables.

$\mathrm{Vi}=\mathrm{pH} 7$ and for other parameters it is equal to zero, but for DO Vi $=14.6 \mathrm{mg} / \mathrm{L}$

$\mathrm{Sq}=$ Recommended $\mathrm{WHO}$ standard of the parameter. Then, after calculating the quality rating scale $\left(Q_{n}\right)$, the Relative (unit) weight $(\mathrm{Wn})$ was calculated by a value inversely proportional to the recommended standard (Sq) for the corresponding parameter using the following expression-

$$
W n=\frac{K}{X n}
$$

Where,

$W n=$ Relative (unit) weight for nth parameter

$\mathrm{X} \mathrm{n}=$ Standard permissible value for $\mathrm{nth}$ parameter

$\mathrm{K}=$ Proportionality constant.

Finally, the overall WQI was calculated by consolidating the quality ratings with unit weights using the following equation-

$$
W Q I=\frac{\sum Q n W n}{\sum W n}
$$

Where,

Qn = Quality rating

$W n=$ Relative (unit) weight 


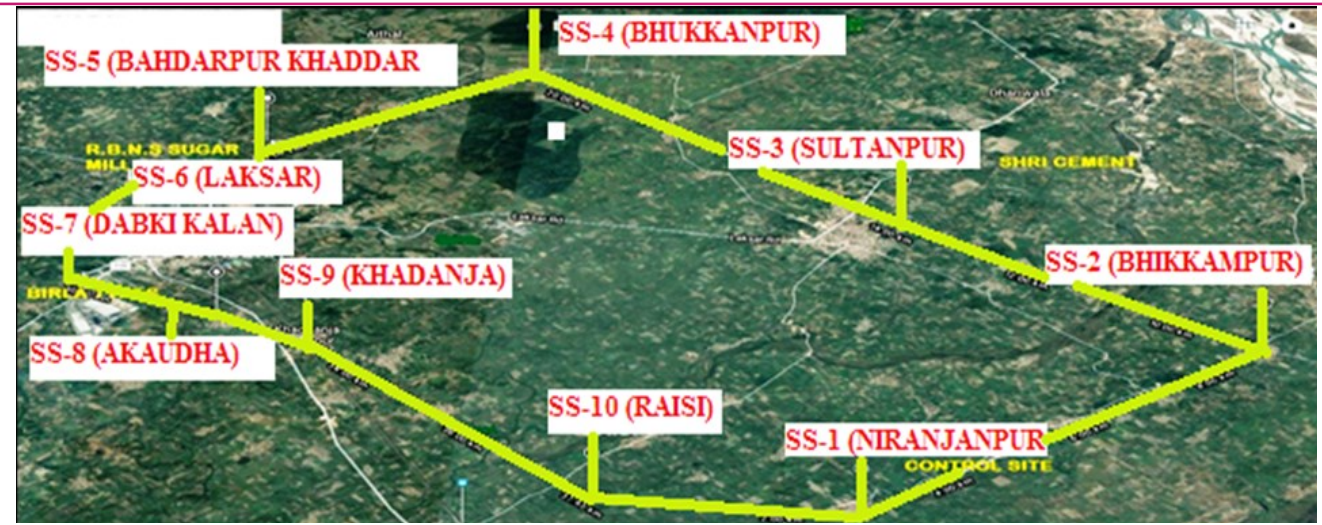

Fig. 1. Showing the map of block Laksar with all the sampling sites (SS-1 to SS-10).

WQI scale and water quality categorization is given in Table 2.

\section{RESULTS AND DISCUSSION}

The results of physicochemical parameters of all the study sites (Niranjanpur (SS-1, Control), Bhikkampurjeetpur (SS-2), SultanpurAdampur (SS-3), Bukkanpur (SS-4), Bahdarpur Khaddar (SS-5), Laksar (SS-6), Dabki Kalan (SS-7), AkaudhaAurangzebpur (SS-8), KharanjaKutubpur (SS-9), Raisi (SS-10)) during the study period from 2017 to 2019 are given in Table 3 . The correlation among all the parameters (Temperature, EC, TDS, TS, pH, DO, TH, CaH, Cl, Sulphate, Nitrate, Acidity and Iron (Fe)) is given in table 4. Temperature of groundwater depends on the temperature of both ground and atmosphere therefore varies with ground and atmospheric temperature. In the first year of study, groundwater temperature ranged from $24.4^{\circ} \mathrm{C}$ to $26.3^{\circ} \mathrm{C}$ and in second year from $24.5^{\circ} \mathrm{C}$ to $25.9^{\circ} \mathrm{C}$. The minimum value of temperature was found at site SS $-5\left(24.4^{\circ} \mathrm{C}\right)$ and maximum value was found at site SS-7 $\left(25.9^{\circ} \mathrm{C}\right)$. The average temperature of both the year was found $25.1^{\circ} \mathrm{C} \pm 0.52$. A negative correlation $(-0.02$ to -0.49$)$ of all the studied parameters was observed with temperature except nitrate $(+0.38)$.

Conductivity can be defined as a measure of the ability of an aqueous medium to carry an electric current. In water, conductivity is due to the presence of various ionic species. In the first year of study, conductivity ranged from $581.7 \mu \mathrm{mhos} / \mathrm{cm}$ to $897.4 \mu \mathrm{mhos} / \mathrm{cm}$ and in second year from $578.3 \mu \mathrm{mhos} / \mathrm{cm}$ to $1019.6 \mu \mathrm{mhos} / \mathrm{cm}$. The minimum value of conductivity was found at site SS-1 $(581.7 \mu \mathrm{mhos} / \mathrm{cm})$ and maximum value was found at site SS-6 $(1019.6 \mu \mathrm{mhos} / \mathrm{cm})$. The average conductivity of both the year was found $813.0^{\circ} \mathrm{C} \mu \mathrm{mhos} / \mathrm{cm}$ +97.00. A strong positive correlation of TDS was observed with EC (+1.00) and with TS (+0.97).

Total Dissolve Solid (TDS) can be defined as a residue of defined evaporated filtered water. In the first year of study, TDS ranged from $377.1 \mathrm{mg} / \mathrm{l}$ to $582.9 \mathrm{mg} / \mathrm{l}$ and in the second year from $375.8 \mathrm{mg} / \mathrm{l}$ to $662.5 \mathrm{mg} / \mathrm{l}$. The $\mathrm{min}-$ imum value of TDS was found at site SS-1 $(375.8 \mathrm{mg} / \mathrm{l})$ and maximum value was found at site SS-6 $(662.5 \mathrm{mg} /$ I). The average TDS of both the year was found $526.7 \mathrm{mg} / \mathrm{l} \pm 63.32$ which was above the standard limit of WHO and BIS $(500 \mathrm{mg} / \mathrm{l})$. Total Solid (TS) can be defined as residue of defined evaporated water. In the first year of study, TS ranged from $510.2 \mathrm{mg} / \mathrm{l}$ to $708.9 \mathrm{mg} / \mathrm{l}$ and in second year from $507.1 \mathrm{mg} / \mathrm{l}$ to $782.4 \mathrm{mg} / \mathrm{l}$. The minimum value of SS was found at site TS-1 (507.1 $\mathrm{mg} / \mathrm{l})$ and maximum value was found at site SS-6 $(782.4 \mathrm{mg} / \mathrm{l})$. The average TS of both the year was found $647.9 \mathrm{mg} / \mathrm{I} \pm 62.97$. Strong positive correlation

Table 1. Geological coordinates of sampling sites of study area (Laksar block, Haridwar Uttarakhand).

\begin{tabular}{|c|c|c|c|}
\hline Sampling sites & Latitude & Longitude & $\begin{array}{l}\text { Distance form } \\
\text { control site }\end{array}$ \\
\hline SS-1: Niranjanpur & $30^{\circ} 17^{\prime} 50.6436^{\prime \prime} \mathrm{N}$ & $78^{\circ} 0^{\prime} 36.4068^{\prime \prime} \mathrm{E}$ & Control site \\
\hline SS-2: Bhikkampurjeetpur & $29^{\circ} 43^{\prime} 57.2088^{\prime \prime} \mathrm{N}$ & $78^{\circ} 9^{\prime} 32.7708^{\prime \prime} \mathrm{E}$ & $6.4 \mathrm{KM}$ \\
\hline SS-3: SultanpurAdampur & $29^{\circ} 45^{\prime} 39.3408^{\prime \prime} \mathrm{N}$ & $78^{\circ} 6^{\prime} 54.378^{\prime \prime} \mathrm{E}$ & $9.0 \mathrm{KM}$ \\
\hline SS-4: Bukkanpur & $29^{\circ} 48^{\prime} 11.4768^{\prime \prime} \mathrm{N}$ & $78^{\circ} 3^{\prime} 44.424^{\prime \prime} \mathrm{E}$ & $16.3 \mathrm{KM}$ \\
\hline SS-5: Bahdarpur Khaddar & $28^{\circ} 29^{\prime} 35.7216^{\prime \prime} \mathrm{N}$ & $77^{\circ} 18^{\prime} 10.7712^{\prime \prime} \mathrm{E}$ & 18.3KM \\
\hline SS-6: Laksar & $29^{\circ} 45^{\prime} 13.8348^{\prime \prime} \mathrm{N}$ & $78^{\circ} 1 ' 17.3352^{\prime \prime} \mathrm{E}$ & $16.6 \mathrm{KM}$ \\
\hline SS-7: Dabki Kalan & $29^{\circ} 44^{\prime} 29.256^{\prime \prime} \mathrm{N}$ & $78^{\circ} 0^{\prime} 39.5136^{\prime \prime} \mathrm{E}$ & $14.8 \mathrm{KM}$ \\
\hline SS-8: AkaudhaAurangzebpur & $29^{\circ} 44^{\prime} 42.3924^{\prime \prime} \mathrm{N}$ & $78^{\circ} 3^{\prime} 3.3408^{\prime \prime} \mathrm{E}$ & $11.4 \mathrm{KM}$ \\
\hline SS-9: KharanjaKutubpur & $29^{\circ} 43^{\prime} 51.6936^{\prime \prime} \mathrm{N}$ & $78^{\circ} 2^{\prime} 33.846^{\prime \prime} \mathrm{E}$ & $11.4 \mathrm{KM}$ \\
\hline SS-10: Raisi & $29^{\circ} 41^{\prime} 58.0128^{\prime \prime} \mathrm{N}$ & $78^{\circ} 4^{\prime} 49.17^{\prime \prime} \mathrm{E}$ & $6.3 \mathrm{KM}$ \\
\hline
\end{tabular}


Table 2. Water Quality Index (WQI) and its status according to Chaterjee and Raziuddin (2002).

\begin{tabular}{ll}
\hline $\begin{array}{l}\text { Water quality Index } \\
\text { Level }\end{array}$ & $\begin{array}{l}\text { Water Quality } \\
\text { Status }\end{array}$ \\
\hline $0-25$ & Excellent water quality \\
$26-50$ & Good water quality \\
$51-75$ & Poor water quality \\
$76-100$ & Very poor water quality \\
$>100$ & Unsuitable for drinking \\
\hline
\end{tabular}

$(+0.70,+0.80)$ of TDS and TS was observed with iron and moderate positive $(+0.31,+0.40)$ with hardness. $\mathrm{pH}$ is the measure of the intensity of acidity or alkalinity and the measurement of hydrogen ions in water and is expressed as negative $\log _{10}$ of the hydrogen concentration in a solution. In the first year of study, $\mathrm{pH}$ ranged from 6.8 to 7.3 and in second year from 6.9 to 7.3. The minimum value of SS was found at site SS-2 (6.8) and maximum value was found at site SS-10 and SS-4 (7.3). The average $\mathrm{pH}$ of both the years was found $7.1 \pm 0.14$. Weak negative correlation was observed between $\mathrm{pH}$ and other parameters except DO (+0.23).

Dissolved oxygen (DO) in water is the indicator of the health of water. The minimum value of DO was found at site SS-2 $(5.9 \mathrm{mg} / \mathrm{l})$ and maximum value was found at site SS-3 $(6.7 \mathrm{mg} / \mathrm{l})$. The average DO of both the years was found $6.3 \mathrm{mg} / \mathrm{l} \pm 0.16$. Very weak to moderate negative correlation was observed between DO and other studied parameters except $\mathrm{pH}(+0.23)$ and nitrate (+0.69).

Hardness is the ability of water to reduce and destroy lather soap. Hardness in water is caused by natural accumulation of salts from soil contact and may enter by direct pollution from geological formations or industrial effluents. Calcium and Magnesium are the principle cations causing hardness. The minimum value of $\mathrm{TH}$ was found at site SS-3 $(89.9 \mathrm{mg} / \mathrm{l})$ and maximum value was found at site SS-6 $(389.0 \mathrm{mg} / \mathrm{l})$. The average $\mathrm{TH}$ of both the years was found $268.4 \mathrm{mg} / \pm 991.53$. The minimum value of $\mathrm{CaH}$ was found at site SS-3 $(44.8 \mathrm{mg} / \mathrm{l})$ and maximum value was found at site SS-6 $(319.0 \mathrm{mg} /$ I). The average $\mathrm{CaH}$ of both the years was found $187.4 \mathrm{mg} / \pm 92.30$. Moderate positive correlation of harness was found with TS $(+0.40,+0.35)$ and TDS $(+0.31,+0.26)$ strong positive correlation with chloride $(+0.72,+0.78)$ and iron $(+0.70,+0.78)$. Jain et al. (2010) reported the similar range of hardness $(88 \mathrm{mg} / \mathrm{l}$ to $438 \mathrm{mg} / \mathrm{l}$ ) in the groundwater of district Nainital, Uttarakhand, India.

The minimum value of chloride was found at site SS-10 $(43.4 \mathrm{mg} / \mathrm{l})$ and maximum value was found at site SS-9 (143.2mg/l). The average chloride of both the year was found $87.5 \mathrm{mg} / \pm 29.26$. The minimum value of sulphate $\left(\mathrm{SO}_{4}{ }^{-}\right)$was found at site SS-2 $(26.50 \mathrm{mg} / \mathrm{l})$ and maximum value was found at site SS-9 $(43.8 \mathrm{mg} / \mathrm{l})$. The av- erage sulphate of both the years was found $34.5 \mathrm{mg} /$ \pm 5 .26 Sulphate was observed positively correlated with most of studied parameters except temperature, $\mathrm{pH}$ and DO. Similar results of sulphate $(20 \mathrm{mg} / \mathrm{l}$ to $37 \mathrm{mg} / \mathrm{l})$ in the groundwater of Smalkhan in Haryana were reported by Kumari and Rani (2014).

The minimum value of nitrate was found at site SS-1 $(1.6 \mathrm{mg} / \mathrm{l})$ and maximum value was found at site SS-3 $(27.1 \mathrm{mg} / \mathrm{l})$. The average nitrate of both the year was found $6.6 \mathrm{mg} / \mathrm{l} \pm 7.16$. The minimum value of acidity was found at site SS-1 $(61.3 \mathrm{mg} / \mathrm{l})$ and maximum value was found at site SS-3 $(105.92 \mathrm{mg} / \mathrm{l})$. The average acidity of both the year was found $82.3 \mathrm{mg} / \pm 5$. 10 . Iron is an essential element of human nutrition. Adsorption of iron from the intestine in the form of FA is an important part of human metabolism. The minimum value of iron was found at site SS-1 $(0.12 \mathrm{mg} / \mathrm{l})$ and maximum value was found at site SS-6 $(0.48 \mathrm{mg} / \mathrm{l})$. The average iron of both the year was found $0.3 \mathrm{mg} / \mathrm{l} \pm 0.11$. Zaware et al. (2015) reported similar results $(0.01 \mathrm{mg} / \mathrm{l}$ to $0.97 \mathrm{mg} / \mathrm{l})$ of $\mathrm{Fe}$ in the groundwater of Raigad in Maharashtra.

\section{Water quality index of groundwater}

Sub index of each parameter and WQI of each site is given in the Table 5 . The results based on the weighted arithmetic water quality index (WQI) calculated by using all the parameters and taking Standard values of WHO (2011) and BIS (2012) as reference values and taking iron as criteria pollutant at each site because of its highest sub index value indicated that from SS-1 to SS-10, the least concerning parameter was sulphate except at SS-2 (pH) and SS-10 (Chloride). At SS-1 (Niranjanpur, Control site), the WQI was 46.46 indicating that water quality was in good condition.

The WQI values of the sites SS-2 (Bhikkampurjeetpur, WQI-78.81), SS-3 (SultanpurAdampur, WQI-54.66), SS -4 (Bhukkanpur, WQI-68.40), SS-5 (Bahdarpur Khaddar, WQI-71.40), SS-6 (Laksar, WQI-150.27), SS-7 (Dabki Kalan, WQI-118.49), SS-8 (Akaudha Aurangzebpur , WQI-132.17), SS-9 (KharanjaKutubpur, WQI110.56), and SS-10 (Raisi, WQI-94.45), indicated that water quality of the study area was in poor condition and not suitable for drinking at these sites. The water quality of the site SS-10 (Raisi, WQI-94.45) was in very poor condition. The water of the site SS-6 (Laksar, WQI -150.27) was most polluted, while that of SS-1 (Niranjanpur- Control site-WQI-46.46) was least polluted. During site visits, negligible water polluting activities were observed at Niranjanpur-control site.

Similar observations of groundwater quality based on WQI in other areas of India have been observed in Thirumanimuttar sub-basin (WQI:37.94 to 298.96; poor to very poor) of Tamil Nadu by Vasanthavigar et al. (2010), in Smalkhan area (WQI: 89.09 to 146.67; poor) of Panipat, Haryana by Kumari and Rani (2014), in South Chennai (WQI: 45.62 to 622.10; excellent to 


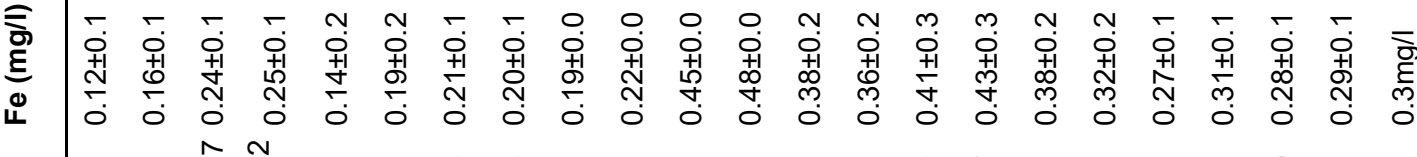

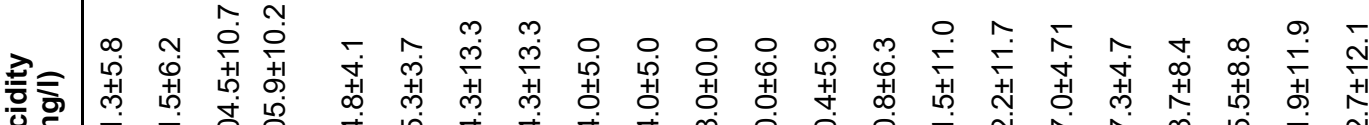

$\overbrace{}^{2}$

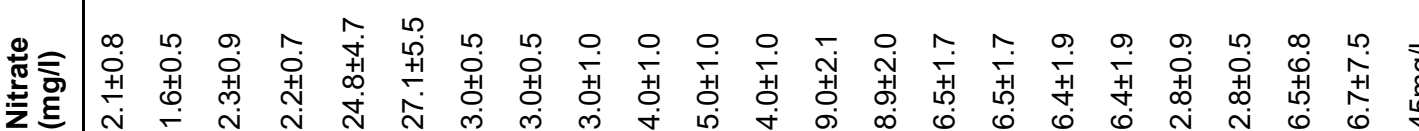

¿े̀

은

ఖ

足

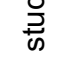

$\stackrel{\oplus}{\rightleftarrows}$

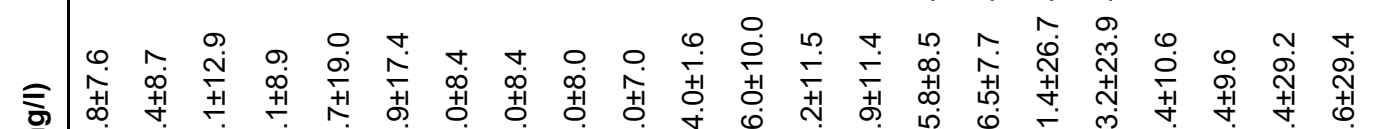

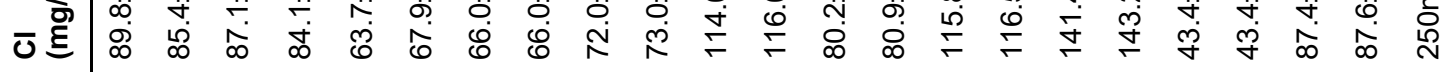

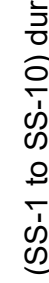

$\stackrel{\Phi}{\frac{\Phi}{\omega}}$

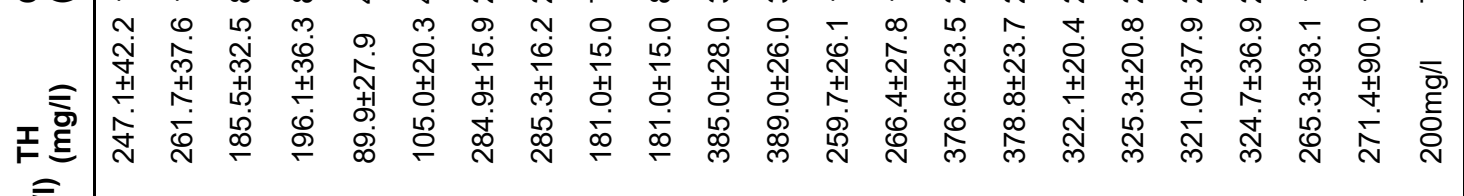

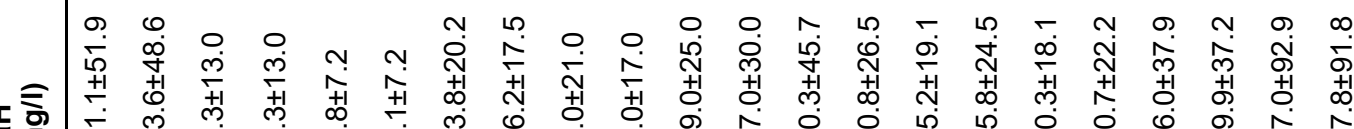

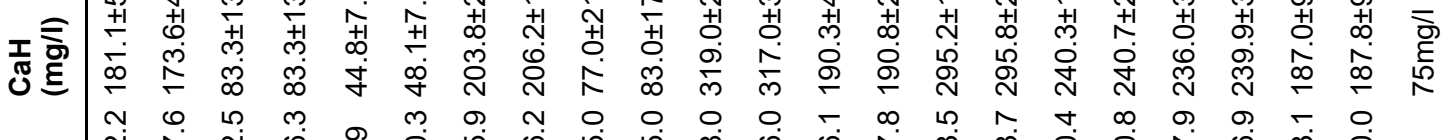

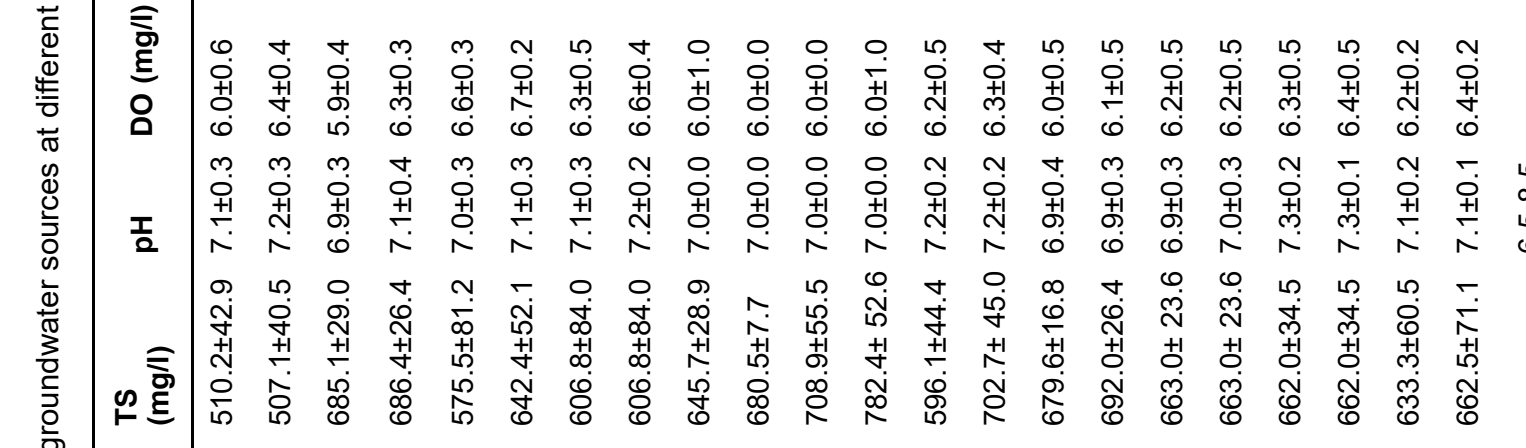

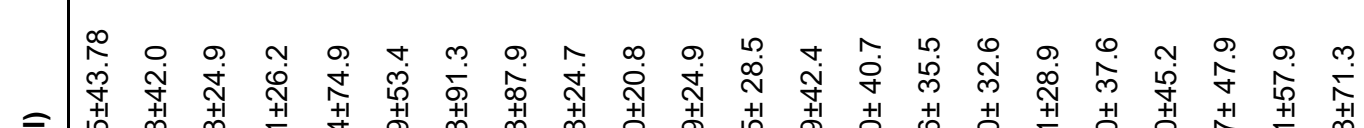

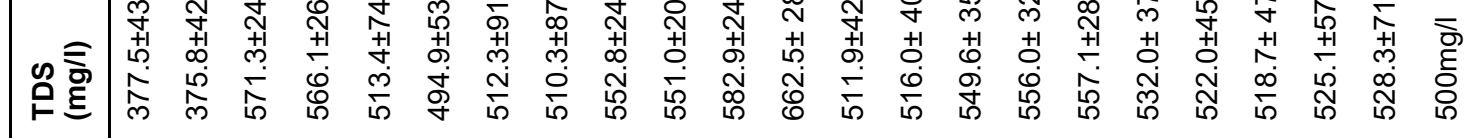

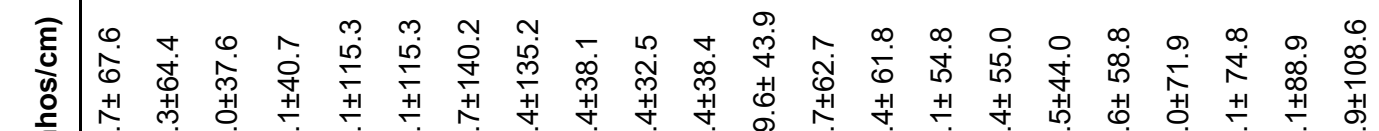

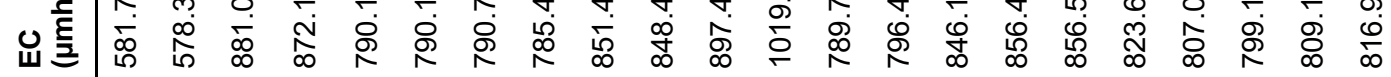

造

$\frac{\text { के }}{\frac{0}{2}}$

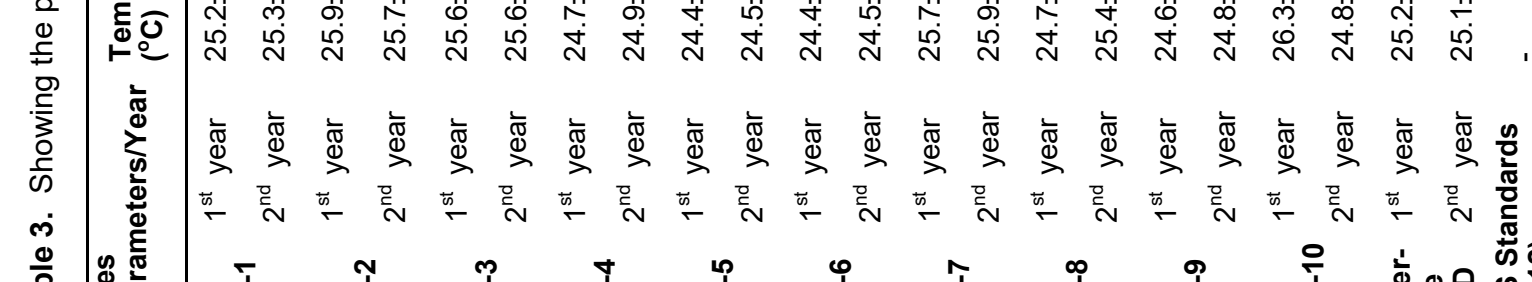

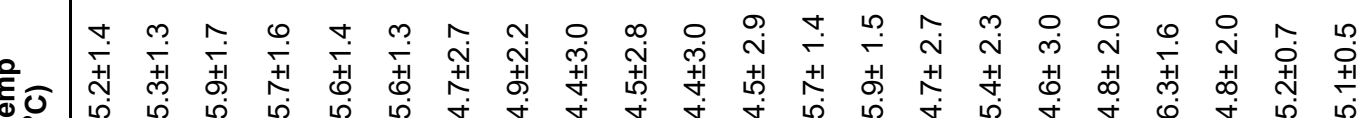

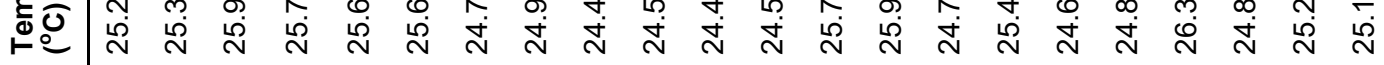

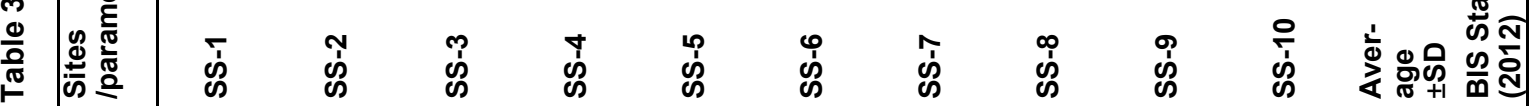


Bhutiani, R. et al. / J. Appl. \& Nat. Sci. 13(1): 197 - 203 (2021)

Table 4. Showing correlation between studied parameters.

\begin{tabular}{lllllllllllll}
\hline $\begin{array}{l}\text { Parame- } \\
\text { ters }\end{array}$ & EC & Temp & TDS & TS & pH & TH & CaH & DO & Sulphate & Nitrate & CI & Iron \\
\hline EC & 1.00 & & & & & & & & & & & \\
Temp & -0.31 & 1.00 & & & & & & & & & & \\
TDS & 1.00 & -0.33 & 1.00 & & & & & & & & & \\
TS & 0.97 & -0.29 & 0.98 & 1.00 & & & & & & & & \\
pH & -0.06 & -0.26 & -0.05 & -0.06 & 1.00 & & & & & & & \\
TH & 0.28 & -0.49 & 0.31 & 0.40 & -0.05 & 1.00 & & & & & & \\
CaH & 0.24 & -0.46 & 0.26 & 0.35 & -0.02 & 0.98 & 1.00 & & & & & \\
DO & -0.15 & -0.02 & -0.18 & -0.34 & 0.23 & -0.61 & -0.51 & 1.00 & & & & \\
Sulphate & 0.15 & -0.18 & 0.15 & 0.22 & -0.35 & 0.51 & 0.54 & -0.24 & 1.00 & & & \\
Nitrate & 0.00 & 0.38 & -0.04 & -0.09 & -0.16 & -0.52 & -0.39 & 0.69 & 0.14 & 1.00 & & \\
Cl & 0.32 & -0.36 & 0.34 & 0.43 & -0.44 & 0.72 & 0.70 & -0.60 & 0.65 & -0.25 & 1.00 & \\
Iron & 0.68 & -0.27 & 0.70 & 0.80 & -0.05 & 0.78 & 0.78 & -0.55 & 0.57 & -0.17 & 0.68 & 1.00 \\
\hline
\end{tabular}

poor) of Tamil Nadu by Kumar et al. (2014), in different parts of Varanasi (WQI: 41.65 to 113.70; poor) by Chaurasia et al. (2018) and in Bokaro district ( WQI: 38.85 to 228.16; poor) of Jharkhand by Verma et al. (2020).

\section{Conclusion}

The present study concluded that the maximum concentration of most of the parameters like EC, TDS, TS, TH, and Fe was observed at SS-6 (Laksar) of Laksar block of Haridwar district in Uttarakhand that may be due to the direct industrial discharge on the ground surface mostly from small and large scale sugar industries, tyre industry and cement industry. The values of TDS, $\mathrm{TH}, \mathrm{CaH}$, and $\mathrm{Fe}$ of groundwater at the sites SS6 (Laksar), SS-7 (DabkiKalan), SS-8 (Akaudha Aurangzebpur), SS-9 (KharanjaKutubpur) and SS-10 (Raisi) were beyond the standards while that of nitrate, sulphate and chloride of the groundwater were below the WHO and BIS standards at all the sites. Based on WQI values, SS-6 (Laksar) was the most polluted site (WQI150.27), while SS-1 (Niranjanpur) was the least polluted (WQI-46.46) site. It is suggested that care should be taken that there is no direct industrial discharge on the ground surface to avoid contamination of the groundwater quality of the area. The study may be useful for managing the groundwater quality of the study area.

\section{Conflict of interest}

The authors declare that they have no conflict of interest.

\section{REFERENCES}

1. Adimallaa, N. and Qiana, H. (2019). Groundwater quality evaluation using water quality index (WQI) for drinking purposes and human health risk (HHR) assessment in an agricultural region of Nanganur, south India. Ecotoxicology and Environmental Safety, 176: 153-161. https:// doi.org/10.1016/j.ecoenv.2019.03.066

2. APHA (2012). Standard Methods for the examination of Water and Wastewater, Lenore S C, Greenberg A E, Eaton A D,(Eds.), 20th Edition, American Public Health Association, NW, Washington, DC.

3. Bahmani, O. and Palangi, S. (2018). Assessment of Groundwater Quality in Human Health Risk, Agriculture and Industry with the Qualitative Indices in the Bahar Plain, West Iran. Asian Journal of Water, Environment and Pollution, 15(4), 81-88. DOI: 10.3233/AJW-180060

4. Bhutiani, R., Kulkarni, D. B., Khanna, D. R. and Gautam, A. (2016). Water Quality, Pollution Source Apportionment and Health Risk Assessment of Heavy Metals in Groundwater of an Industrial Area in North India. Exposure and Health 8, 3-18. DOI 10.1007/s12403-015-0178-2

5. Bhutiani, R., Ram, K. and Ahamad, F. (2019). Assessment of suitability of groundwater quality in and around Laksar, Haridwar, Uttarakhand on the basis Water Quality Index (WQI). Environment Conservation Journal, 20(1-2), 41-46. https://doi.org/10.36953/ECJ.2019.1008.1207

6. Bhutiani, R., Ram, K., Taygi, V., Ahamad, F. and Kaushik, P. (2018a). Assesment of groundwater quality of Laksar block in district Haridwar, Uttarakhand. Environment Conservation Journal, 19(3), 123-128. https://doi.org/10.3 6953/ECJ.2018.19316

7. Bhutiani, R., Ahamad, F., Tyagi, V. and Ram, K. (2018b). Evaluation of water quality of River Malin using water quality index (WQI) at Najibabad, Bijnor (UP) India. Environment Conservation Journal, 19 (1\&2), 191-201. https:// doi.org/10.36953/ECJ.2018.191228

8. Bhutiani, R. and Ahamad, F. (2018). Efficiency assessment of sand intermittent filtration technology for wastewater treatment. International Journal of advance research in science and engineering (IJARSE), 7(03), 503 -512 .

9. BIS (2012). Indian standard drinking water specification, Second Revision ISO: 10500:2012, Bureau of Indian Standards (BIS), Drinking Water Sectional Committee, FAD25. New Delhi, India.

10. Biswas, A. K. and Tortajada, C. (2019). Water quality management: A globally neglected issue. International Journal of Water Resources Development, 35(6), 913916, DOI: 10.1080/07900627.2019.1670506 
11. Brown, R. M., McClelland, N. I., Deininger, R. A., Tozer, R. G. (1970). A water quality index-do we dare? Water sewage works, 117, 339-343.

12. CGWB (2016). Aquifer Mapping and Ground Water Management Plan. Central Ground Water Board (CGWB), Ministry of Water Resources, River Development and Ganga Rejuvenation Government of India, pp.1-75.

13. Chaterjee, C. and Raziuddin, M. (2002). Determination of water quality index (WQI) of a degraded river in Asanol Industrial area, Raniganj, Burdwan, West Bengal. Nature Environment and Pollution Technology, 2, 181-189.

14. Chaurasia, A. K., Pandey, H. K., Tiwari, S. K., Prakash,R., Pandey, P. and Ram, A. (2018). Groundwater Quality assessment using Water Quality Index (WQI) in parts of Varanasi District, Uttar Pradesh, India. Journal Geological Society of India, 92, 76-82.

15. Cude, C. (2001). Oregon water quality index: A tool for evaluating water quality management effectiveness. Journal of the American Water Resources Association, 37: 125-137.

16. Jain, C. K., Bandyopadhyay, A. and Bhadra, A. (2010) Assessment of groundwater quality for drinking purpose, district Nainital, Uttarakhand, India. Environmental Monitoring Assessment, 166, 663-676.

17. Kaviarasan, M., Geetha, P. and Soman, K. P. (2016). GIS -based groundwater monitoring in Thiruvannamalai District, Tamil Nadu, India. International Conference on Soft Computing Systems, 397, 685-700.

18. Khan, R. and Jhariya, D. C. (2017). Groundwater quality assessment for drinking purpose in Raipur city, Chhattisgarh using water quality index and geographic information system. Journal Geological Society of India, 99, 69-76.

19. Khanna, D. R. and Bhutiani, R. (2008). Laboratory manual of water and Waste water Analysis. Daya Publishing House New Delhi -110002.

20. Kumar, V., Kumar, S., Srivastava, S., Singh, J. and Kumar, P. (2018). Water quality of River Ganga with reference to physicochemical and microbiological characteristics during Kanwar Mela 2017, at Haridwar, India: A case study. Archives of Agriculture and Environmental Science, 3 (1), 58-63. https://doi.org/10.26832/24566632.2018.03 0108

21. Kumar, S. K., Bharani, R., Magesh, N. S., Godson, P. S., Chandrasekar, N. (2014). Hydrogeochemistry and groundwater quality appraisal of part of south Chennai coastal aquifers, Tamil Nadu, India using WQI and fuzzy logic method. Applied Water Science, (2014) 4, 341-350. DOI 10.1007/s13201-013-0148-4

22. Kumari, S. and Rani, J. (2014). Assessment of water quality index of Groundwater in smalkhan, Haryana. International Journal of Latest Research in Science and Technology, 3 (6): 169 - 172.

23. Kwami, I. A., Ishaku, J. M., Bello, A. M., Yusuf, A., Abubakar, U. and Mukkafa, S. (2018). Assessment of Water Quality Index for the Groundwater in Gombe and Environs, North-east Nigeria. Journal of Applied Geology and Geophysics, 6(5): $29-37$

24. Milovanovic, M. (2007). Water quality assessment and determination of pollution sources along the Axios Vardar River Southeastern Europe. Desalination, 213, 159-173. https://doi.org/10.1016/j.desal.2006.06.022
25. Rao, K. N. and Latha, P. S. (2019). Groundwater quality assessment using water quality index with a special focus on vulnerable tribal region of Eastern Ghats hard rock terrain, Southern India. Arabian Journal of Geosciences, 267, 2-16. https://doi.org/10.1007/s12517-019-4440-y

26. Ruhela, M, Wani, A. A. and Ahamad, F. (2020). Efficiency of Sequential Batch Reactor (SBR) based sewage treatment plant and its discharge impact on Dal Lake, Jammu \& Kashmir, India. Archives of Agriculture and Environmental Science, 5(4), 517-524, https://dx.doi.org/10.26832/245 66632.2020.0504013

27. Sadat, N. S. M., Ebrahimi, K. and Liaghat, A. M. (2014). Groundwater quality assessment using the water quality index and GIS in Saveh- Nobaran aquifer, Iran. Environmental Earth Science, 71: 3827-3843. DOI 10.1007/ s12665-013-2770-8

28. Saleh, H. N., Valipoor, S., Zarei, A., Asghari, M. Y. F. B., Mohammadi, A. A., Ghalehaskar, F. A. S. and Khaneghah, A. M. (2020). Assessment of groundwater quality around municipal solid waste landfill by using Water Quality Index for groundwater resources and multivariate statistical technique: A case study of the landfill site, Qaem Shahr City, Iran. Environ Geochemistry Health, 42, 1305-1319. https://doi.org/10.1007/s10653-019-00417-0

29. Toure, A., Wenbiao, D. and Keita, Z. (2017). Comparative Study of the physicochemical quality of water from wells, boreholes and rivers consumed in the commune of Pelengana of the Region of Segou in Mali. Environmental Science an Indian Journal, 13(6,: 1-12

30. Vaiphei, S. P., Kurakalva, R. M. and Sahadevan, D. K. (2020). Water quality index and GIS-based technique for assessment of groundwater quality in Wanaparthy watershed, Telangana, India. Environmental Science and Pollution Research, 27, 45041-45062 https://doi.org/10.1007/ s11356-020-10345-7

31. Vasanthavigar, M., Srinivasamoorthy, K., Vijayaragavan, K., Ganthi, R. R., Chidambaram, S., Anandhan, P., Manivannan, R. and Vasudevan, S. (2010). Application of water quality index for groundwater quality assessment: Thirumanimuttar sub-basin, Tamilnadu, India. Environment Monitoring Assessment, 17, 595-609. DOI 10.1007/ s10661-009-1302-1

32. Verma, D. K., Bhunia, G. S., Shit, P. K. and Tiwari, A. K. (2018). Assessment of groundwater quality of the central gangetic plain area of India using geospatial and WQI techniques. Journal Geological Society of India, 92: 743752

33. Verma, P., Singh, P. K., Sinha, R. R. and Tiwari, A. K. (2020) Assessment of groundwater quality status by using water quality index (WQI) and geographic information system (GIS) approaches: a case study of the Bokaro district, India. Applied Water Science, 10, 27, https:// doi.org/10.1007/s13201-019-1088-4

34. WHO (2011). Guidelines for drinking-water quality, 4th edn. World Health Organization, Geneva.

35. Zaware, S. G., Patil, V. V. and Zaware, P. S. (2015). Assessment of Groundwater Quality and its Impact on Human health at Padghe in Raigad District, Maharashtra, India. International Research Journal of Environment Sciences, 4(5), 57-61 